\title{
Analysis of the effects of COVID 19 on the operations and sustainability of SMEs in South Western region, Uganda
}

\author{
Arthur Sunday*, Caleb Tamwesigire, Abanis Turyahebwa, Kaaya Siraje, Eliab Byamukama \\ Department of Business Studies, Faculty of Economics and Management Science, Kabale University, Uganda.
}

Received 11 September, 2020; Accepted 14 July, 2021

\begin{abstract}
SMEs are considered huge boosters to the economy of Uganda. They serve as the engine and driving force for growth, development, innovation, economic prosperity and wealth creation of Uganda. The study aimed at establishing the upshot of COVID 19 on the operations and sustainability of SMEs in Uganda with a view to creating a lucid model for successful SMEs operations and improved performance. The study examined factors for efficient operations and sustainability for SMEs in Uganda. The study embraced a positivist quantitative approach with correlational design and cross sectional, survey design, underpinned on the interpretivism philosophy. The study used a sample of 205 SMEs working in Kabale, Kisoro, Rukiga, Rukungiri and Ntungamo. The findings revealed that COVID19 pandemic accounted for a significant variance in the operations and sustainability of SMEs in the selected boarder districts in Uganda. The study confirmed the hypothesis that the effects of COVID19 pandemic have positively affected performance, operations and sustainability of SMEs. The pecking order theory was largely supported by the study and resource based view lays the ground in explaining, sustainability, performance and operations of SMEs in Uganda. The study recommends that the respective government of Uganda authorities and partners offer appropriate liquidity intercessions to support SMEs in handling instant liquidity encounters, to avoid closures and bankruptcies.
\end{abstract}

Key words: COVID 19, operations, performance, sustainability, small and medium enterprise, business.

\section{INTRODUCTION}

On 11th March 2020, the World Health Organization declared COVID-19 a global pandemic. COVID-19 has affected the operation of businesses of all types and sizes globally, regionally, at national and local levels. Globally there is an anticipated economic recess with less than $10 \%$ of economic growth being attained by the first half of the year (IMF, 2020). McKinsey has referred to COVID-19 as the twin threats to both lives and livelihoods including businesses. Given the vulnerability and fragile nature of Small and Medium Enterprises, these have not been spared by COVID19. The Uganda Investment Authority outlook indicated that over 30, 0000 jobs had been eroded by covid19 between January and May, 2020. With the increase in the total number of COVID19 cases and "upslope" of the pandemic, the impact on SMEs is likely to increase and also call for 
business diversification to respond to and cater for the changing demands (Barro et al, 2020). The Economic Policy Research Centre (2020) survey alludes that SMEs faced a greater deterioration in business undertakings compared to larger enterprises majorly because of their vulnerable operational procedures and inability to implement core CPOVID19 preventive measures and standards. However, have all SMEs been affected the same way? This study explored deep into the margin of impact for service sector firms and those in agriculture and manufacturing while maintaining the assumption that the severity of COVID-19 on SMEs has been felt across the spectrum.

Business growth and enterprise development remain key engines for national growth and development (World Bank, 2016) and COVID19 had an increase in the operational costs for both The study provided information on the regional impact of covid19 on businesses in south western region in Uganda and the dynamics that come with the cross border districts and boundaries with Congo, Rwanda and Burundi.

In Uganda, SMEs sector contributes $20 \%$ to Gross Domestic Product and it provides engagement to over 1.5 million people which accounts for $90 \%$ of total nonfarming private sector workers (UIA, 2008). The paybacks of the small and medium enterprises in Ugandan economy cannot be overemphasized. SMEs play a pivotal part in employment and income generation and help in conscription of local resources (Ernst and Young, 2011). Regardless of the remarkable contributions of SMEs to the Ugandan economy, the aptitudes of the SMEs have not been fully subjugated and this is a concern of all stakeholders in the economy (UNCTAD, 2002; Ekanem, 2010; Kazooba, 2006). SMEs underperformance has been attributed to poor access to finances (Kasekende and Opondo, 2003) and commonly lack of strategic resources in agreement with the resource dependency theory which promulgated by Barney (1991a). Barney (1991b) emphasizes that businesses could underperform due to insufficient resources and this could therefore be extended to SMEs underperformance as a result of COVID 19 (Craven et al, 2020).

Uganda is a growing economy with an annual growth rate of $3 \%$ according to the Uganda Bureau of Statistics reports. Small and Medium Enterprises contribute over $70 \%$ of Uganda's Gross Domestic Product and 90\% employment opportunities (Turyahebwa et al, 2013). The informal sector contributes a bigger percentage to GDP annually. As part of containing the spread of COVID-19, Uganda adopted stringent measures including a total lock down of the economy. The lock down alone condensed business undertakings with over $50 \%$ in given sectors (EPRC, 2020) a complete shutdown in other sectors. Subsequent restrictions on logistics and supply chain management activities, ban on weekly markets and closed operations of other business activities had immense negative implication on movement of labor, access to raw materials and inputs for some SMEs, lack of market for goods and services and undermined the production processes across the various levels of the business value chain (New Vision, 2020). There has also been an overall increase in the prices of commodities and inputs varying across the sectors and regions. For example, businesses in central and eastern parts of Uganda reported an increase in operational expenditure of more than $25 \%$ from the normal operational costs. Less information is available about the effect in south western districts which has a lot of business processes in agriculture, tourism and manufacturing sectors and is also a source of raw materials. Therefore, this research seeks to fill the gap and provide information on the effect of COVID19 on the operations of SMEs in south western region to critically inform the design of a suitable COVID19 recovery plan by both the business owners and government.

The overall purpose of the study was to establish the effect of COVID19 on the operations and sustainability of Small and Medium Enterprises with a view to creating a comprehensible model to enhance sustainability of SMEs during and after COVID19, with a hypothetical assumption that there is a positive and significant effect of COVID19 pandemic on the operations and sustainability of SMEs in South western Uganda.

\section{LITERATURE REVIEW}

While covid-19 is relatively a new occurrence, there is literature on its impact on various sectors of the economy. What is largely available are global, regional and national data on the different dimensions of the pandemic. Less attention has been paid on geographical differences even when it is obvious that regions will be affected differently and as such cope differently irrespective of the national standard measures and standard operating procedures.

\section{Global impact of COVID19 on businesses}

According to McKinsey (2020), social distancing, restrictions on travel, and quarantines, measures leads to a shrill fall in customer and business spending until the end of Quarter2, leading to a recession. Though the outbreak was contained in most parts of the world in late Quarter2, the dynamic forces of a recession kick in and elongated the slump until the end of Quarter3. Shoppers are kept home, revenues drop and workers are laid off, thus sparking off unemployment. While this provides a global and general business outlook, there is need for specific information on SMEs and more so those located and doing business in selected south western Uganda districts. 


\section{COVID19 and SMEs}

SMEs operate in various production and service sectors, these have been stunnered differently with those involved in tourism, hotels and hospitality sectors, education and overall service sectors as the most hit (Lakuma and Nathan, 2020). The presidential address has seldom referred to some sectors as economies of leisure and pleasure thus, attracting less sympathy and recovery support from government. For SMEs involved in agriculture and manufacturing, the effects have been mixed including access to markets, ability to meet their clients' demands among others. This has been alluded to by the Economic Policy Research Centre (2020) analysis on the impact of COVID19 on SMEs. There is limited information on how the sectors are coping at regional level and specifically in the south western region which this study will address. The 2020 EPRC study mentioned that COVID19 has generally affected small businesses through limited supply, reduced demand, travel restrictions and reduced mobility of people, goods and services. With the growth of Information and Communication Technologies (ICT), how SMEs are coping is not very clear.

\section{Theoretical underpinning}

Various theories have been advanced to explain what influences performance of businesses. Numerous theories which have been put forward to explain the performance of SMEs include: Resource-Based View of the firm as advanced by Wernerfelt (1984), Barney (1991a), Pecking Order Theory Myers and Majluf (1984), Shyam-Sunder and Myers (1999), Knowledge-Based view Grant (1996), and Dynamic Capabilities Theory by Teece et al. (1997). These theories try to explain performance of SMEs irrespective of their limitations (Table 1).

\section{Philosophical assumptions}

The study trails a positivist view which is quantitative in nature and which trusts that the objects under study are unaffected by their research activities and will continue even when the study is completed. This is because this study placed an early commitment to theoretical constructs formulated before gathering data and thereafter employed the quantitative designs based on an objective view of the world, which follows the positivist model of testing pre-specified hypotheses as commended by Denzin and Lincoln (2008). The study used rational positivism quantitative designs because it is not biased since it relates to phenomenon and relies a lot on statistics and results from the study.

\section{RESEARCH METHODOLOGY}

The study adopted a quantitative paradigm since it involved theory testing and was made of variables which were measured in numbers and they were later analyzed with statistical tools as required in positivist realm (Creswell, 2003). The study used a number of designs in order to obtain meaningful results as Guba and Lincoln (1994) observed that no single design should be seen as a universal panacea. The study employed exploratory study design (Cooper and Schindler, 2008). The exploratory study was used to define the notions to be encompassed in the study theory and to back the foundation and background of the study. This was an intensive exploratory and survey study on the existing literature and secondary data available on COVID 19 and operations and sustainability of SMEs which involved review of literature. The study used a descriptive design in order to describe the profile of the respondents in terms of age group of owners, level of education, number of years in present business and the perceptions of respondents regarding COVID 19 as well as operations and sustainability of SMEs. The study also used a cross sectional research design as the study intended to obtain a random sample as well as understand a cross section of interest at a particular time. Cross-sectional studies are useful for generating and clarifying hypothesis and they help in laying the ground work for decisions about future follow up studies (Kraemer, 1983). However, cross-sectional studies cannot answer questions about the stability of a characteristic or process overtime (Miller, 1998). Furthermore, the correlation design was used to explore and determine the extent of the relationships between COVID 19 and sustainability of SMEs. The study set out to ascertain the connection between the study variables, and extent of COVID 19 pandemic impact on the operations and sustainability of SMEs. The study population consisted of SMEs in the districts of Kabale, Rukungiri, Rukiga, Kisoro and Ntungamo. The SMEs were the units of analysis. Owners/ Managers of SMEs were the units of inquiry.

Many scholars propose different ways of arriving at an appropriate and representative sample. However, this study adopted probability sampling methods with representatives of the different SMEs having an equal chance to participate in the study. The SMEs were surveyed with a view to understand the impact of COVID19 on business operations. It is important to note however, that there are no definitive prescriptions about the adequate size of a sample for a study, but larger samples are preferred in quantitative studies.

\section{RESULTS}

To explore the impact of COVID on small businesses, a survey was conducted on more than 200 small and medium businesses, out of which male respondents represented about $63 \%$ and female respondents represented $37 \%$ (Figure 1). Overall majority of the small and medium businesses have employees ranging from 1 to 5 as this represents $69 \%$ with those businesses that are slightly bigger having a range of 21 and above employees with just about 4\% (Table 2). Majority of the small businesses are family business. This represents a $50 \%$ with limited companies only taking about $4 \%$. The sole proprietorship takes about 34\% (Table 3).

\section{SECTOR ANALYSIS}

Regarding the main sector of activity of the business, the findings revealed that a bigger percentage of SMEs surveyed belong to the wholesale and retail (26\%), closely followed by Construction and carpentry (12\%), 
Table 1. Theoretical underpinning.

\begin{tabular}{|c|c|c|c|}
\hline Theory & Details about content & Limitations & Source \\
\hline Resource Based View & $\begin{array}{l}\text { Suggests that in business, resources and products are two sides of the same } \\
\text { coin. It links profitability with the resources used. The theory tries to give details } \\
\text { on the internal sources of a business's sustained competitive advantage. }\end{array}$ & $\begin{array}{l}\text { It has no managerial implications, it } \\
\text { implies infinite regress. The definition of a } \\
\text { resource is unworkable }\end{array}$ & $\begin{array}{l}\text { Wernerfelt (1984), Barney, 2001, } \\
\text { 1999,1996, 1991a, 1991b), Miller } \\
\text { (2003), Armstrong and Shimizu } \\
\text { (2007) }\end{array}$ \\
\hline Pecking Order Theory & $\begin{array}{l}\text { A firm's financing is determined by the firm's preference to finance with } \\
\text { internally generated funds instead of with external financing. If external } \\
\text { financing is required, debt is preferred over equity. The highest preference is to } \\
\text { use internal financing and only look at any form of external funds as a last } \\
\text { resort. }\end{array}$ & $\begin{array}{l}\text { Whereas the pecking order theory has an } \\
\text { impact on finance capital structure, it is } \\
\text { also criticized for its simplifying } \\
\text { assumptions, where the firm's only } \\
\text { financing choice is debt vs. equity }\end{array}$ & $\begin{array}{l}\text { Myers (1984), Myers and Majluf } \\
\text { (1984), Ang, 1992, Shyam- } \\
\text { Sunder and Myers (1999) }\end{array}$ \\
\hline Knowledge Based Theory & $\begin{array}{l}\text { The knowledge based theory considers knowledge as the most important of the } \\
\text { firm's resources. }\end{array}$ & $\begin{array}{l}\text { There is insufficient consensus as to its } \\
\text { purpose. This theory does not give details } \\
\text { about the nature of heterogeneous asset } \\
\text { bases that are suitable to different } \\
\text { businesses in conjunction with their } \\
\text { objectives. }\end{array}$ & Grant (1996) \\
\hline Dynamic Capabilities Theory & $\begin{array}{l}\text { This theory attempts to provide details into how dynamic capabilities facilitate } \\
\text { achievement of business performance by responding fast to external and } \\
\text { internal environmental changes }\end{array}$ & $\begin{array}{l}\text { Dynamic capabilities do not engage in the } \\
\text { production of a marketable good or } \\
\text { service. Instead, they build, integrate or } \\
\text { reconfigure functional competences. }\end{array}$ & Teece et al., 1997, Winter (2003) \\
\hline
\end{tabular}

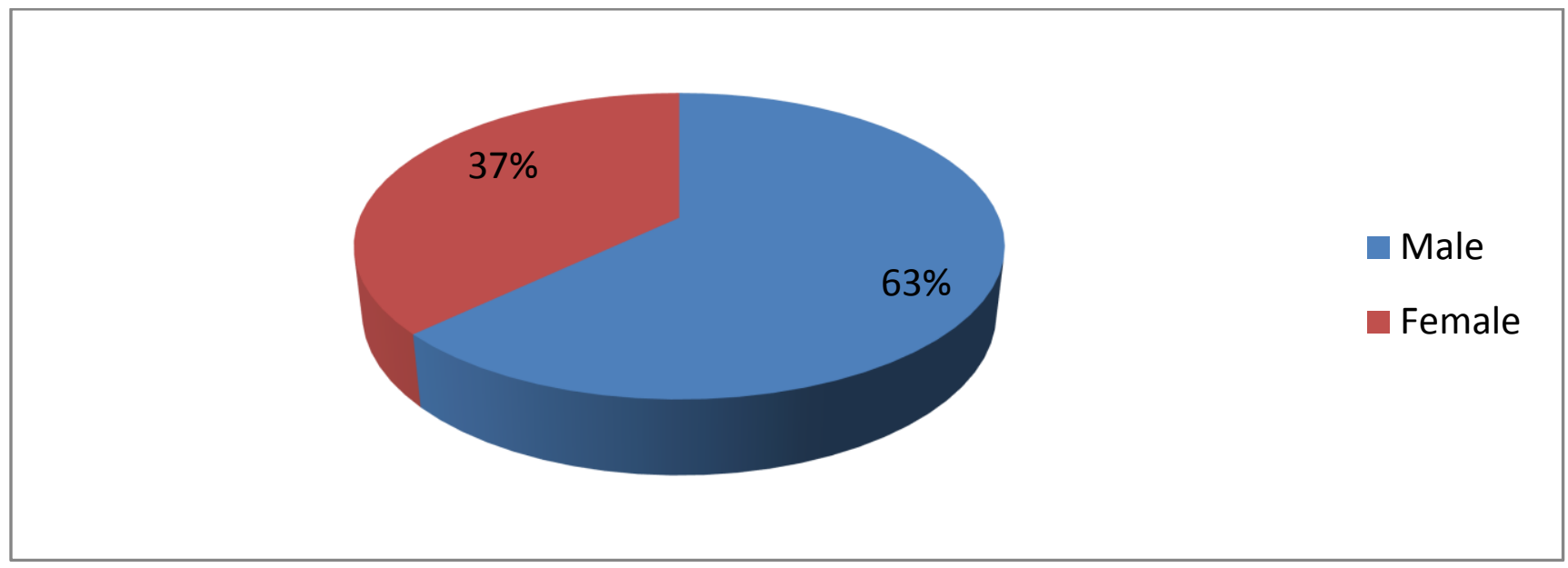

Figure 1. Gender of respondents.

Source: Field Primary Data, 2020. 
Table 2. Number of employees in respondents organization.

\begin{tabular}{lcc}
\hline Number of employees in respondents organization & Frequency & Percent \\
\hline $1-5$ & 142 & 69.3 \\
$6-10$ & 34 & 16.6 \\
$11-15$ & 14 & 6.8 \\
$16-20$ & 6 & 2.9 \\
21 and above & 9 & 4.4 \\
Total & 205 & 100 \\
\hline
\end{tabular}

Source: Field Primary Data, 2020.

Table 3. The Legal form of business.

\begin{tabular}{lcc}
\hline Legal form of business & Frequency & Percent \\
\hline Family business & 103 & 50.2 \\
Sole proprietorship & 69 & 33.7 \\
Partnership & 24 & 11.7 \\
Limited Company & 9 & 4.4 \\
Total & 205 & 100.0 \\
\hline
\end{tabular}

Source: Field Primary Data, 2020.

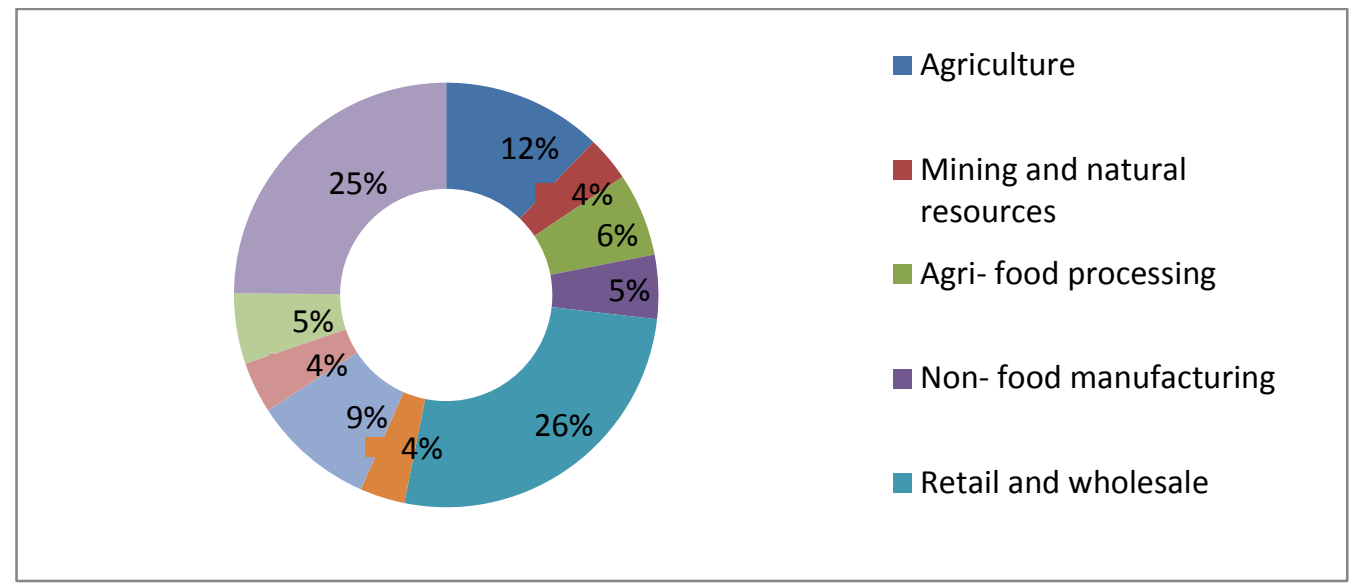

Figure 2. Main Sector of the business.

Source: Field Primary Data, 2020.

followed by agriculture (9\%). The remaining SMEs belong to mining and natural resources, non-food manufacturing, travel and transport, accommodation and food services, financial services (Figure 2). Overall, $72 \%$ of the businesses do not envisage business closure save for the negative effects of the pandemic on their businesses. About $15 \%$ expect businesses to close within 6 months if the situation remains the same and $5 \%$ expect their businesses to permanently shut down in one month as a result of Covid-19 related effects. Therefore, micro and small firms are more susceptible to the risk associated with COVID-19 pandemic than medium and large firms (Table 4).

Findings from the perception survey results, revealed $30.2 \%$ that the business environment for the Period MarMay 2020 was good to operate in than before while $69.8 \%$ mentioned that the business situation was worse than before (Table 5). Survey findings revealed that $50 \%$ of the business situation for the next 2 months will be better, while another $51 \%$ expected the business situation to worsen in the next 2 months if the situation remains the same. This will not look good for the 
Table 4. Risk that SMEs business will permanently close down due to the effect of COVID 19 Pandemic.

\begin{tabular}{|c|c|c|c|c|}
\hline $\begin{array}{l}\text { Risk that SMEs business will permanently stop the operations due to the } \\
\text { effect associated with COVID } 19 \text { Pandemic }\end{array}$ & Frequency & Percent & Valid Percent & Cumulative Percent \\
\hline 1 Month or less & 11 & 5.4 & 5.4 & 5.4 \\
\hline 3 Months & 16 & 7.8 & 7.8 & 13.2 \\
\hline Business closure not envisaged & 148 & 72.2 & 72.2 & 100.0 \\
\hline
\end{tabular}

Source: Field Primary Data, 2020.

Table 5. Business Performance outside the normal expectation due to COVID19.

\begin{tabular}{lcccc}
\hline Variable & Frequency & Percent & Valid Percent & Cumulative Percent \\
\hline Yes & 143 & 69.8 & 69.8 & 69.8 \\
No & 62 & 30.2 & 30.2 & 100.0 \\
Total & 205 & 100.0 & 100.0 & \\
\hline
\end{tabular}

Source: Field Primary Data, 2020.

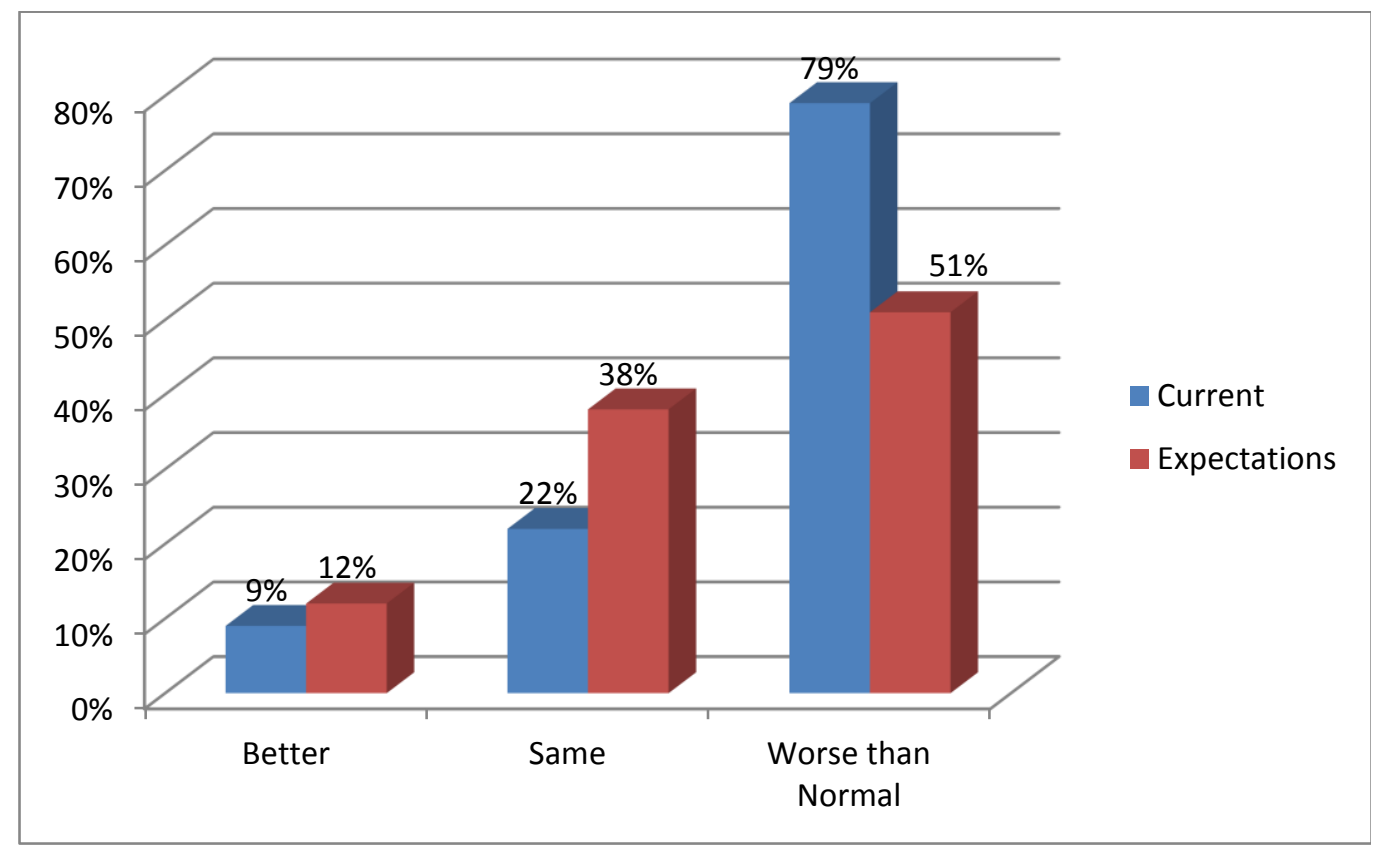

Figure 3. Expectation of SMEs performance in the next two months in comparison with the current situation of COVID 19 Pandemic. Source: Field Data.

sustainability of businesses in the economy (Figure 3 ). The study findings revealed that, in the period of March to May, revenue declined due to COVID-19 across all SMEs by $71 \%$, with estimated average sales reduction at $70 \%$, however the SMEs hoped to continue operational. It was further noted that a high percentage of SMEs in the services sector in particular reported a decline in access to credit and financial liquidity compared to large businesses. This was attributed to the fact that lending institutions already consider them highly risky, and those businesses are more likely to become insolvent if COVID19 persists and restrictions are maintained (Figure 4).

On the impact of the Covid19 pandemic has had on the business operations, figure above shows that $86 \%$ of the respondents mentioned that it has had a negative effect, $10 \%$ mentioned it had a positive effect while $4 \%$ were not 


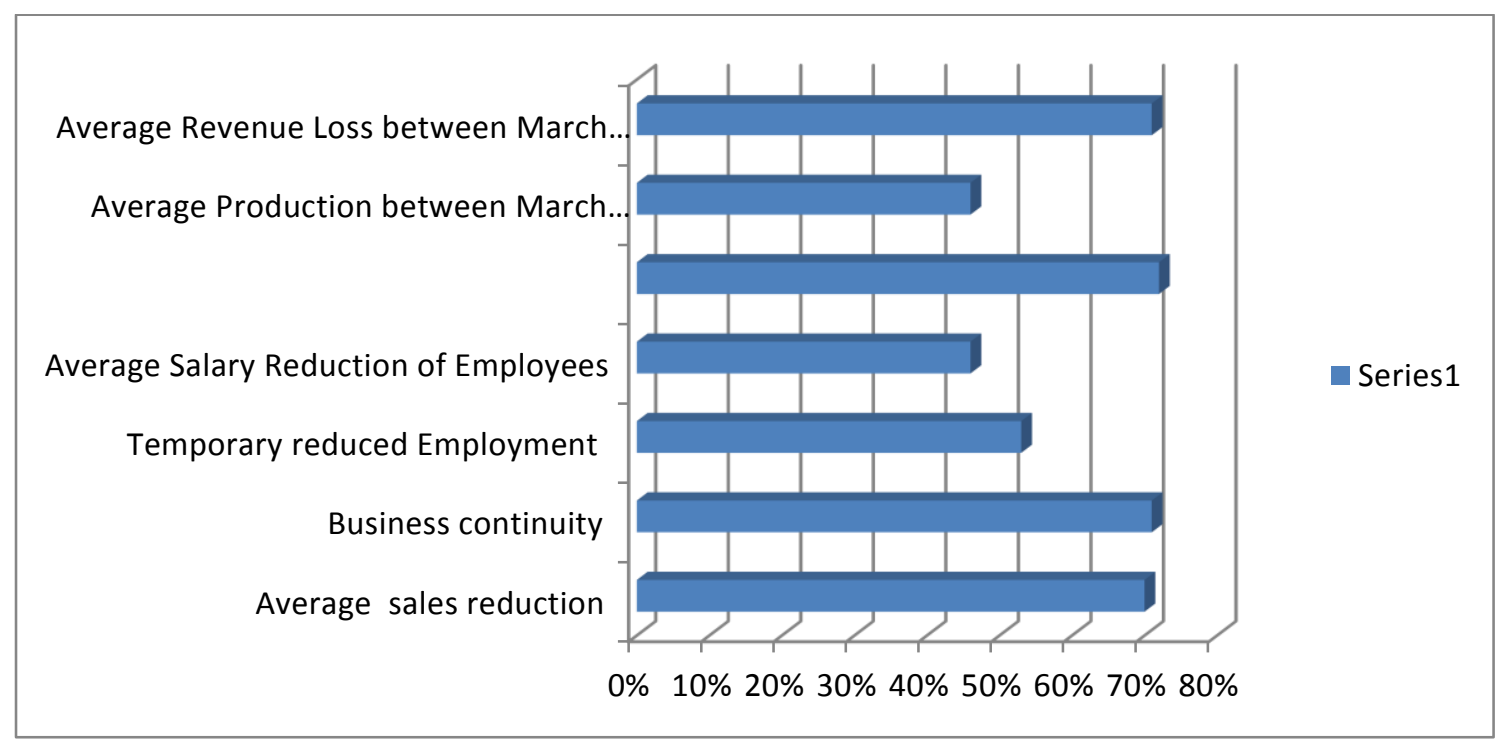

Figure 4. SMEs Performance Analysis.

Source: Field Primary Data, 2020.

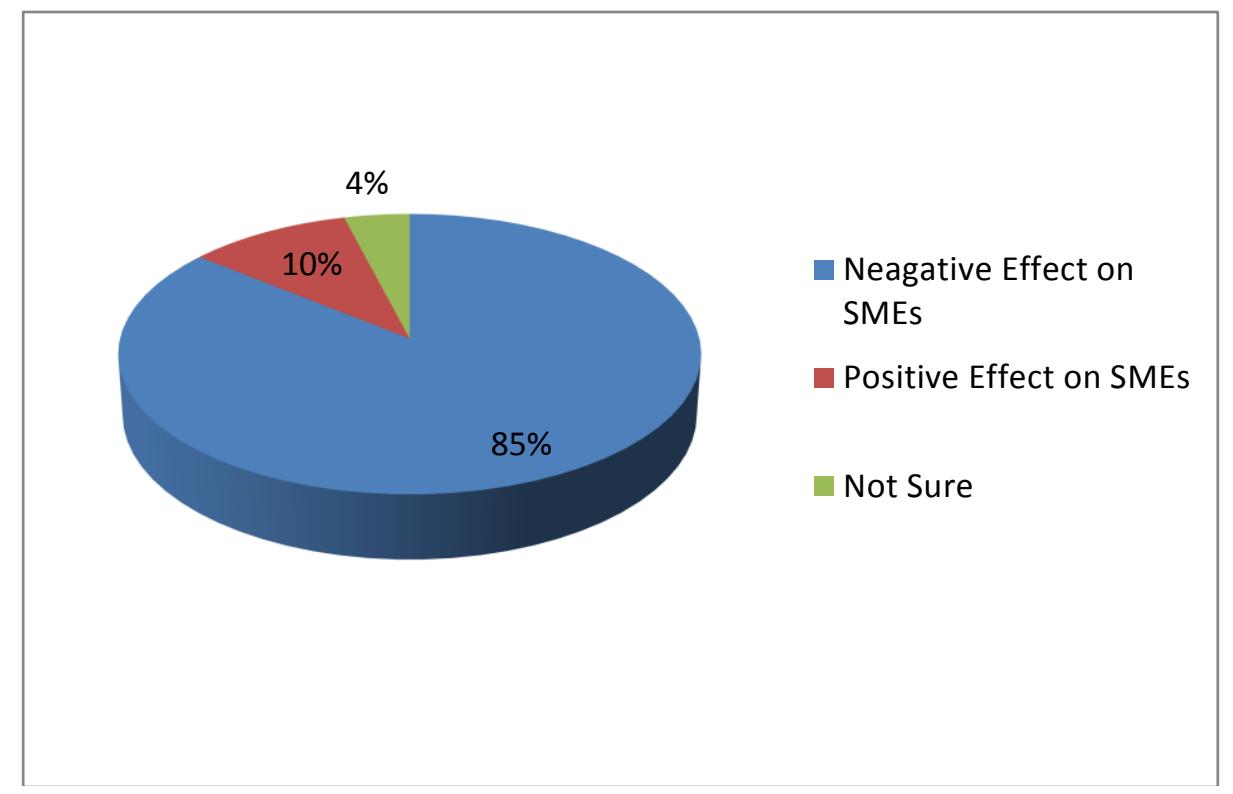

Figure 5. Perceptions on general effect of COVID-19 on operations of SMEs.

Source: Field Primary Data, 2020.

sure. Generally SMEs have been hit negatively hard by the impact of the COVID 19 in this business period between March 2020 and May 2020 (Figure 5). The results presented revealed that COVID 19 significantly explains $45.9 \%$ of the total variance in Operations of SMEs from the period under consideration (Adjusted $\left.\mathrm{R}^{2}=0.459, p=0.00\right)$. This implies that $54.1 \%$ of the variance is accounted for by other factors other than those considered under this model. Furthermore, the regression model is a best fit because it statistically and significantly predicts the variance in Operations of SMEs caused by the effects of COVID 19 ( $F=158.631, p=0.00<$ 0.05). In general, the results show that COVID 19 has had a positive and significant effect on Operations of SMEs. This therefore supports the hypothesis that there is significant effect of COVID 19on Operations of SMEs $(p<0.05)$ (Table 6).

The results presented revealed that COVID 19 
Table 6. The Effect of COVID 19 on Operations of SMEs in Selected Districts in Uganda.

\begin{tabular}{lcc}
\hline COVID 19 & Standardized Coefficients Beta $(\boldsymbol{\beta})$ & Significance $(\boldsymbol{p})$ \\
\hline Adjusted $R 2=0.459$ & 0.679 & 0.000 \\
$F=158.631, p=0.000$ & & \\
\hline
\end{tabular}

Dependent Variable: Operations of SMEs.

Table 7. The Effect of COVID 19 on Sustainability of SMEs in Selected Districts in Uganda.

\begin{tabular}{lcc}
\hline COVID 19 & Standardized Coefficients Beta $(\boldsymbol{\beta})$ & Significance $(\boldsymbol{p})$ \\
\hline Adjusted $R^{2}=0.369$ & 0.610 & 0.000 \\
$F=109.917, p=0.000$ & & \\
\hline
\end{tabular}

Dependent Variable: Sustainability of SMEs.

significantly accounts for $36.9 \%$ of the total variance in Sustainability of SMEs in the period under review and consideration (Adjusted $R^{2}=0.369, p=0.00$ ). This implies that $63.1 \%$ of the variance is accounted for by other factors other than those considered under this model. Furthermore, the regression model is good fit because COVID 19 can statistically and significantly predict the variance in Sustainability of SMEs ( $F=109.917$, $p=0.00<0.05$ ). Generally, the results show that COVID 19 has had a positive and significant effect on Sustainability of SMEs. This therefore accepts the hypothesis that there is significant effect of COVID 19 on Sustainability of SMEs $(p<0.05)$ in selected districts in Uganda (Table 7).

\section{DISCUSSION}

In this study, the impact of COVID-19 on operations and sustainability of SMEs has been comprehensively discussed. The results presented in the previous section signify the huge impact of COVID-19 on SMEs' performance, operations and sustainability of SMEs in Uganda. The findings in this study have also been validated from most previous research, in which significant impact of COVID-19 on operational procedures and sustainability of SMEs has been observed. According to Hamiza (2020), COVID-19 pandemic has forced many SMEs and organizations to identify innovative operational procedures to ensure the effective flow of business operations in uncertain situations of COVID-19. Similarly, as per the study of McCausland (2020), due to the situation of COVID-19, companies have had to quickly adapt to the new market situation by reshaping the way they operate or by inventing themselves. In this manner, the innovative operational procedures of SMEs are greatly influenced by COVID-19.

This research's primary findings also confirm the significant but negative impact of Covid-19 on SMEs' performance. Also validated from various studies, the negative impact of Covid-19 on business profitability has been widely acknowledged in the previous literature. According to (Xiong et al., 2020), the COVID-19 pandemic and resulting lockdowns have negatively impacted SMEs, as these businesses have faced several issues related to logistics blocks, shortages of labor, and a significant decline in consumer demand. All these issues related to the COVID-19 pandemic have caused a significant decline in the SME's profitability. The findings are in agreement with the study conducted by Shen et al., (2020), in which it has been argued that most of the business deals are closing due to the COVID-19 pandemic. This study's primary outcomes confirm the significant impact of COVID-19 on operations and sustainability of SMEs.

\section{Conclusion and recommendations}

From the survey, it has been revealed that SMEs in Uganda are highly been affected by COVID-19 and associated business restrictions. We recommend that the government should offer liquidity interventions, offer tax credits, tax rate reduction to support SMEs in addressing liquidity challenges. Financial institutions should consider providing emergency loans to SMEs with flexibility in repayments. The Government should extend partial credit guarantee schemes for loans provided by commercial banks to enable SMEs acquire credit facilities and boost their investments. Practioners should offer training to the SMEs owners on how to adopt and implement efficient working capital management practices so as to ensure improved performance of SMEs. The training should focus on how easily and feasible the Cash Conversion Cycle (CCC) of SMEs can be reduced so as to have sustainable liquidity to help SMEs finance their short term obligations. Similarly, there is need to emphasize the importance of keeping proper books of accounts and also 
to convince owner managers to have a positive attitude towards financial reporting as this will help the SMEs owners to know the financial performance and position of their businesses.

SMEs access to finance was found to be a big challenge, thus the policy makers should provide a favorable platform for SMEs to access financing that can enable them to run their businesses at a reasonable cost of financing. This is necessary since the access to bank loans is difficult by SMEs and they end up using only internally generated funds. The interest rates should be favourable; similarly the requirements to accessing such funding should also be reasonable so as not to push SMEs to money lenders whose interest rates are exorbitant. The Capital Markets Authority (CMA) and Uganda Securities Exchange should also think about a way on how moderate SMEs can raise funds through the stock exchange by floating their shares in a moderate market.

\section{Implications for practice}

The results from this study should be viewed as a contribution to the knowledge the effect of COVID 19 on small and medium business. The government of Uganda can use the finding of this study develop appropriate strategies to support small businesses in a bid to rescue since SMEs are great contributors to the Ugandan economy. Finally, this article highlights the voice of both entrepreneurs and managers on the effect of COVID 19 on sustainability of SMEs and this may aid in diagnosing the required remedies, given the gravity of its impact.

\section{Limitations of the findings}

This is interpreted in the context of the potential limitations of this study. The qualitative approach provides depth to our understanding of this problem but may not be generalizable to all SMEs and all business settings in western Uganda. Only SMEs owners and business practitioners operating in Kabale, Kisoro, Rukiga, Rukungiri and Ntungamo were interviewed, thus further work should explore how these experiences vary across businesses in the whole country. In all qualitative studies, findings may be influenced by the perspectives of the investigators.

\section{CONFLICT OF INTERESTS}

The authors have not declared any conflict of interests.

\section{REFERENCES}

Ang JS (1992). On the theory of finance for privately held firms. The
Journal of Entrepreneurial Finance 1(3):185-203.

Armstrong CE, Shimizu K (2007). A review of approaches to empirical research on the resource-based view of the firm. Journal of Management 33(6):959-986.

Barney JB (1991a). Firm resources and sustained competitive advantage. Journal of Management 17(1):99-120.

Barney JB (1991b). Special theory forum the resource-based model of the firm: origins, implications, and prospects. Journal of Management 17(1):97-98.

Barney JB (1996). The resource-based theory of the firm. Organization Science 7(5):469-469.

Barney JB (1999). How a firm's capabilities affect boundary decisions. Sloan Management Review 40(3):137-145.

Barney JB (2001). Is the resource-based "view" a useful perspective for strategic management research? Yes. Academy of Management Review 26(1):41-56.

Barro RJ, Ursúa JF, Weng J (2020). The coronavirus and the great influenza pandemic: Lessons from the "spanish flu" for the coronavirus's potential effects on mortality and economic activity (No. w26866). National Bureau of Economic Research. Available at: https://www.nber.org/papers/w26866

Craven M, Liu L, Mysore M, Wilson M (2020). COVID-19: Implications for business. McKinsey \& Company. pp. 1-8. Available at: https://covid19.bangkokhealth.com/wp-content/uploads/2021/01/Keycriteria-for-the-ethical-acceptability-of-COVID-19-human-challengestudies-2.pdf

Creswell JW (2003). Research Design: Qualitative, Quantitative, and Mixed Methods Approaches. Available at https://books.google.com.ng/books/about/Research_Design.html?id= nSVxmN2KWeYC\&redir esc $=y$

Cooper DR, Schindler PS (2008). Business Research Methods: MaCGraw Hill Int.

Denzin NK, Lincoln YS (2008). The landscape of qualitative research (Vol. 1). Sage.

Ekanem I (2010). Liquidity management in small firms: a learning perspective. Journal of Small Business and Enterprise Development 17(1): 123-138.

Economic Policy Research Centre (EPRC) (2020). How has the COVID-19 Pandemic impacted Ugandan businesses? Results from a business climate survey. Available at: http://library.health.go.ug/publications/disease-survielanceoutbreaks/how-has-covid-19-pandemic-impacted-ugandanbusinesses

Ernst and Young (2011). It's time for Africa: Africa's attractiveness survey. Available at: https://www.casafrica.es/sites/default/files/contents/document/toc000 0003525001.pdf

Grant RM (1996). Toward a knowledge-based theory of the firm. Strategic Management Journal 17(S2):109-122.

Guba EG, Lincoln YS (1994). Competing paradigms in qualitative research. Handbook of Qualitative Research 2(163-194):105.

Hamiza O (2020). The Impact of Coronavirus Lockdown on Small Scale Businesses in Arua Municipality, Uganda. International Journal of Science and Research 9(8):1239-1248.

IMF (2020). IMF Annual Report 2020: A year like no other. Available at: https://www.imf.org/external/pubs/ft/ar/2020/eng/

Xiong J, Lipsitz O, Nasri F, Lui LM, Gill H, Phan L, Chen-Li D, lacobucci M, Ho R, Majeed A, McIntyre RS (2020). Impact of COVID-19 pandemic on mental health in the general population: A systematic review. Journal of Affective Disorders 277(1):55-64.

Kasekende L, Opondo H (2003). Financing Small and Medium-scale Enterprises (SMEs): Uganda's Experience. Available at: http://citeseerx.ist.psu.edu/viewdoc/summary?doi=10.1.1.196.8161

Kazooba CT (2006). Causes of small business failure in Uganda: a case study from Bushenyi and Mbarara Towns. Available at: http://ir.must.ac.ug/handle/123456789/648

Kraemer HC (1983). Theory of estimation and testing of effect sizes: Use in meta-analysis. Journal of Educational Statistics 8(2):93-101.

Lakuma CP, Nathan S (2020). Impact of COVID-19 on micro, small, and medium businesses in Uganda. Available at https://www.brookings.edu/blog/africa-in-focus/2020/05/19/impact-ofcovid-19-on-micro-small-and-medium-businesses-in-uganda/ 
Miller T (1998). Technologies of truth: Cultural citizenship and the popular media. University of Minnesota Press.

Miller D (2003). An asymmetry-based view of advantage: towards an attainable sustainability. Strategic Management Journal 24(10):961976.

Myers SC (1984). Capital structure puzzle. NBER Working Paper, (w1393)

Myers SC, Majluf NS (1984). Corporate financing and investment decisions when firms have information that investors do not have. Journal of Financial Economics 13(2):187-221.

McCausland T (2020). COVID-19's Impact on Globalization and Innovation. Available at: https://www.tandfonline.com/doi/full/10.1080/08956308.2020.181350 6

Mckinsey (2020). COVID-19 - implications for business. Available at: https://www.mckinsey.com/business-functions/risk/our-insights/covid19-implications-for-business-2020\#

New Vision (2020). COVID-19 lockdown: Farmers count losses. The New Vision 2020.2 Available https://www.newvision.co.ug/news/1517754/covid-19-lockdownfarmers-count-losses

Shen H, Fu M, Pan H, Yu Z, Chen Y (2020). The impact of the COVID19 pandemic on firm performance. Emerging Markets Finance and Trade 56(10):2213-2230.

Shyam-Sunder L, Myers SC (1999). Testing static tradeoff against pecking order models of capital structure. Journal of Financial Economics 51(2):219-244.
Teece DJ, Pisano G, Shuen A (1997). Dynamic capabilities and strategic management. Strategic Management Journal 18(7):509533.

Turyahebwa A, Sunday A, Ssekajugo D (2013). Financial management practices and business performance of small and medium enterprises in western Uganda. African Journal of Business Management 7(38):3875-3885.

UIA (2008). Uganda: Development of a National Micro, Small and Medium Enterprises (MSMEs) Policy and Strategy.

UNCTAD (2002). Proceedings of the symposium on modalities for financing SMEs in Uganda. United Nations Conference on Trade and Development, New York and Geneva 2002. Available at: https://unctad.org/system/files/official-document/itetebmisc8 en.pdf

Wernerfelt B (1984). A resource-based view of the firm. Strategic Management Journal 5(2):171-180.

Winter SG (2003). Understanding dynamic capabilities. Strategic Management Journal 24(10):991-995.

World Bank Group (2016). World development report 2016: digital dividends. World Bank Publications. 